\title{
Respon Tanaman Bawang Merah Pada Beberapa Jarak Tanam Dalam Pola Tanam Tumpangsari Dengan Jagung
}

\section{The Response of Shallots to Several Spacings in a Multiple Cropping Pattern with Corn}

\author{
Muhsanati ${ }^{1}$, Rintan Putri Demara ${ }^{2}$ Gustian $^{3}$ \\ ${ }^{1,2,3}$ Program Studi Agroteknologi Fakultas Pertanian, Universitas Andalas Padang
}

\section{ARTICLE INFO \\ Article history: \\ DOI: \\ $\underline{10.30595 / p s p f s . v 2 i .176}$}

Submitted:

July 29, 2021

Accepted:

Sept 10, 2021

Published:

Nov 10, 2021

\section{Keywords:}

Corn, Intercropping, Shallots

\begin{abstract}
The implementation of intercropping is one alternative that can be done to increase the diversity of crops cultivated by farmers, due to the increasing activity of land conversion and limited ownership. The practices of growing several types of crops on the same land and time can provide several advantages. The plantation of corn and shallot on the same field and at the relatively same time will contribute to meet the community's needs for food and feed, especially during the current covid-19 pandemic. The use of various spacing of shallot within corn plantations is expected to increase income and land-use efficiency. The results showed that narrow space of shallots $(10 \mathrm{~cm} \times 15 \mathrm{~cm})$ gave a higher unit area yield, and a wider space $(20 \mathrm{~cm} \times 20 \mathrm{~cm})$ gave a higher land equivalence ratio comparing to other plant spacing $(10 \mathrm{~cm} \times 15 \mathrm{~cm}$, and $10 \mathrm{~cm} \times 20 \mathrm{~cm})$.
\end{abstract}

This work is licensed under a Creative Commons Attribution 4.0 International License.

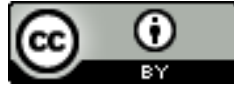

Corresponding Author:

Muhsanati

Program Studi Agroteknologi Fakultas Pertanian, Universitas Andalas Padang

Email: muhsanati@agr.unand.ac.id

\section{PENDAHULUAN}

Peningkatan jumlah penduduk menuntut peningkatan penyediaan pangan, sementara di lain pihak aktifitas alih fungsi lahan serta keterbatasan kepemilikan tidak bisa dihindari. Penanaman tanaman pada lahan terbatas diharapkan dapat meminimalisisir kekurangan akan bahan pangan maupun pakan. Pemanfaatan sebidang tanah dengan menanam beberapa jenis tanaman dapat diupayakan sebagai bentuk pemenuhan kebutuhan gizi dan pangan, serta peningkatan pendapatan penduduk.

Pemilihan pola tanam tumpangsari merupakan salah satu alternatif yang dapat dilakukan untuk menjawab permasalahan tersebut di atas. Dalam hal ini penanaman beberapa jenis tanaman pada lahan yang sama dengan waktu yang hampir bersamaan tentunya dapat memberikan beberapa keuntungan kepada petani.

Pola tanam merupakan faktor penentu yang sangat penting atau merupakan ujung tombak dari sistem produksi tanaman. Pola tanam yang baik harus dapat memanfaatkan dan mengintegrasikan komponenkomponen yang tersedia, seperti lahan, iklim, air, jenis dan varietas tanaman, masukan-masukan, teknik budidaya, pasar, dan sebagainya (Muhsanati, 2011).

Tanaman jagung dan tanaman bawang merah merupakan komuditas yang bernilai ekonomis, karena permintaan yang terus meningkat terhadap kedua komuditas tersebut. Tanaman jagung mengandung karbohidrat yang merupakan sumber makanan pokok setelah padi dan juga sebagai pakan ternak. Sedangkan bawang merah adalah tanaman sayuran bumbu (penyedap) yang bermanfaat bagi kesehatan. 
Konsumsi tanaman jagung untuk pangan maupun pakan cukup tinggi, terutama unggas/ayam perlu diperhatikan karena harga ayam ataupun telur sangat berkorelasi dengan ketersediaan bahan pakannya. Demikian juga kebutuhan terhadap bawang merah terus meningkat, terutama pada waktu-waktu tertentu menyebabkan tingginya harga pasar, sehingga sering menambah pengeluaran dan tidak terpenuhinya kebutuhan di tingkat konsumen. Dengan menyandingkan kedua jenis tanaman ini pada lahan yang sama dan waktu yang relatif bersamaan, tentunya akan berkontribusi dalam pemenuhan kebutuhan masyarakat akan bahan pangan, khususnya selama masa pandemi covid-19 saat ini.

Pada saat ini, jagung sudah menjadi komuditas nasional yang cukup strategis. Penggunaannya sebagai bahan baku pakan ternak cukup mendapat perhatian, baik di kalangan pemerintah maupun swasta. Penggunaan lainnya adalah sebagai sumber minyak pangan dan bahan dasar tepung maizena. Berbagai produk turunan hasil jagung juga digunakan sebagai bahan baku berbagai produk industri farmasi, kosmetik, dan kimia.

Selama periode tahun 2014 sampai 2018, terjadi peningkatan produksi jagung yang cukup signifikan yaitu sebesar 2,68 \%, dan diproyeksikan sampai tahun 2020 akan terjadi surplus jagung. Tahun 2021, 2022, 2023 produksi diramalkan meningkat berturut-turut $0,96 \%$ (30,88 juta ton), 1,08\% (31,21 juta ton) dan 0,02\% (31,22 juta ton), (Kementan, 2018). Selanjutnya ditambahkan oleh Direktorat Jenderal Tanaman Pangan (2019), dalam rentang 5 tahun terakhir, terjadi peningkatan luas panen rata-rata per tahun sebesar 11,06\%, dan produktivitasnya $1,42 \%$. Kebutuhan terbesar ditujukan untuk pakan ternak sebesar $50 \%$, konsumsi pangan $10 \%$, industri 20-30\%, sisanya untuk benih dan tidak digunakan.

Meskipun demikian, kebutuhan jagung nasional belum sepenuhnya dipenuhi dari produksi jagung nasional, karena pola panen jagung yang cendrung konstan selama beberapa bulan setiap tahunnya. Puncak panen hanya terjadi pada bulan Februari, Maret dan April (Kementan, 2018).

Oleh karena itu agar tidak terjadi perebutan sumber daya, dalam hal ini nutrisi atau unsur hara pada kedua tanaman yang ditumpangsarikan, maka perlu dilakukan pengaturan jarak tanam. Penggunaan jarak tanam yang tepat dapat meningkatkan efesiensi penggunaan lahan serta menciptakan iklim mikro yang sesuai. Hasilpenelitian Ratri (2015), mendapatkan nilai kesetraan lahan (NKL) lebih dari satu pada tumpangsari jagung manis dengan daun bawang. Kenyataan ini menunjukkan-bahwa pola tanam yang digunakan mampu meningkatkan produktivitas lahan sehingga lebih efisien daripada sistem tanaman monokultur.

Pada penelitian-Kusmiadi et al. (2015) diperoleh bahwa pada jarak tanam bawang merah $10 \mathrm{~cm} \times 15 \mathrm{~cm}$ memberikan tinggi tanaman tertinggi $(38,23 \mathrm{~cm})$, jumlah anakan dan jumlah umbi yaitu 4,12 siung. Sedangkan pada jarak tanam $20 \mathrm{~cm} \times 15 \mathrm{~cm}$ diperoleh jumlah daun 19,04 helai, bobot basah 21,35 gram, dan bobot kering 16,61 gram. Pada pengamatan komponen hasil, penggunaan jarak tanam tidak berpengaruh, hal ini diduga ketersediaan unsur hara, cahaya matahari dan air yang masih mencukupi.

Hasil tumpangsari jagung dan bawang prei dengan jarak tanam $60 \mathrm{~cm}$ x $50 \mathrm{~cm}$ diperoleh hasil jagung pipilan kering 7,94 ton/ha dan bawang prei 1,6 ton/ha (bobot segar konsumsi), dengan NKL 1,55 (Putra, et al., 2017). Pemilihan tanaman bawang merah pada penelitian ini juga dapat dilakukan dengan menggunakan beberapa jarak tanam.

Penelitian ini bertujuan untuk meningkatkan efesiensi pemanfaatan lahan dalam rangka pemenuhan kebutuhan pangan dan gizi yang selanjutnya dapat meningkatkan pendapatan atau kesejahteraan masyarakat.

\section{METODE PENELITIAN}

\section{Bahan}

Bahan yang digunakan yaitu umbi bawang merah (Allium ascalonicum L.) varietas-Bima Brebes dan benih jagung varietas Pioner 32 , pestisida heksakonazol dan metomil 40\%, air, pupuk KCl, Urea, SP-36 dan ZA.

\section{Alat}

Sedangkan alat yang-digunakan ini adalah cangkul, kamera, ember, meteran, timbangan, selang, sprayer, tali rafia, karung, mulsa hitam perak, kantong plastik, kertas HVS, gunting, pisau, serta.alat tulis.

\section{Rancangan}

Percobaan Penelitian ini menggunakan Rancangan-Acak Kelompok dengan 3 taraf perlakuan dan 3 kelompok. Disamping itu juga terdapat petak monokultur bawang merah dan monokultur jagung. Perlakuan yang digunakan adalah jarak tanam bawang merah, sebagai berikut:

Jarak Tanam $10 \mathrm{~cm} \times 15 \mathrm{~cm}$ (48 populasi / petakan)

Jarak Tanam $10 \mathrm{~cm} \times 20 \mathrm{~cm}(36$ populasi / petakan)

Jarak Tanam $20 \mathrm{~cm} \times 20 \mathrm{~cm}(18$ populasi / petakan $)$

Data=hasil_pengamatan dianalisis secara_statistik menggunakan uji-F pada taraf 5\%. Jika F-hitung perlakuan lebih besar dari F.tabel 5\% maka dilanjutkan uji lanjut dengan Duncan's New Multiple-Range Test (DNMRT). 


\section{HASIL DAN PEMBAHASAN}

\section{Pengamatan Tanaman Bawang Merah}

\section{- Tinggi Tanaman dan Jumlah Daun}

Setelah dilakukan analisis statistik pada pengamatan tinggi tanaman dan jumlah daun bawang merah pada beberapa jarak tanam dalam pola tanam tumpang sari dengan jagung memberikan hasil yang berbeda nyata pada tinggi tanaman, tetapi berbeda tidak nyata pada jumlah daun bawang merah. . Hasil analisis ditampilkan pada tabel berikut.

Tabel 1. Tinggi tanaman dan Jumlah daun bawang merah pada beberapa jarak tanam dalam pola tanam tumpangsari dengan jagung pada umur 5 MST.

\begin{tabular}{lcc}
\hline \multicolumn{1}{c}{ Jarak Tanam } & $\begin{array}{c}\text { Tinggi Tanaman } \\
(\mathrm{cm})\end{array}$ & $\begin{array}{c}\text { Jumlah Daun } \\
\text { (helai) }\end{array}$ \\
\hline $10 \mathrm{~cm} \times 15 \mathrm{~cm}$ & $26,19 \mathrm{a}$ & 10,18 \\
$10 \mathrm{~cm} \times 20 \mathrm{~cm}$ & $23,62 \mathrm{a} \mathrm{b}$ & 10,18 \\
$20 \mathrm{~cm} \times 20 \mathrm{~cm}$ & $20,01 \mathrm{~b}$ & 6,70 \\
\hline $\mathrm{KK}(\%)$ & $7,03 \quad$ & 10,87 \\
\hline
\end{tabular}

Angka-angka pada kolom yang sama diikuti oleh huruf kecil yang sama berbeda tidak nyata menurut uji lanjut DNMRT pada taraf-5\%.

Pada tabel di atas, dapat dilihat bahwa adanya pengaruh beberapa jarak tanam bawang merah terhadap tinggi tanaman. Jarak tanam $10 \mathrm{~cm} \times 15 \mathrm{~cm}$ memberikan nilai angka tinggi tanaman terbesar yaitu $26,19 \mathrm{~cm}$ yang diikuti oleh jarak tanam $10 \mathrm{~cm} \times 20 \mathrm{~cm}(23,62 \mathrm{~cm})$, dan paling rendah diperoleh pada jarak tanam $20 \mathrm{~cm} \times$ $20 \mathrm{~cm}$, yaitu $20,01 \mathrm{~cm}$.

Angka tinggi tanaman yang diperoleh pada jarak yang lebih rapat $(10 \mathrm{~cm} \times 15 \mathrm{~cm})$ merupakan tinggi tanaman yang sesuai dengan deskripsi varietas Brebes yang digunakan. Hasil penelitian ini sejalan dengan penelitian Kusmiadi et al. (2015) yaitu jarak tanam $10 \mathrm{~cm} \times 15 \mathrm{~cm}$ dan $20 \mathrm{~cm} \times 15 \mathrm{~cm}$ memberikan angka tinggi tanaman bawang merah yang tertinggi dari lainnya. Peningkatan laju pertumbuhan pada awal tumbuh lebih cepat, dan melandai setelah 3 MST - 5 MST (Gambar 1).

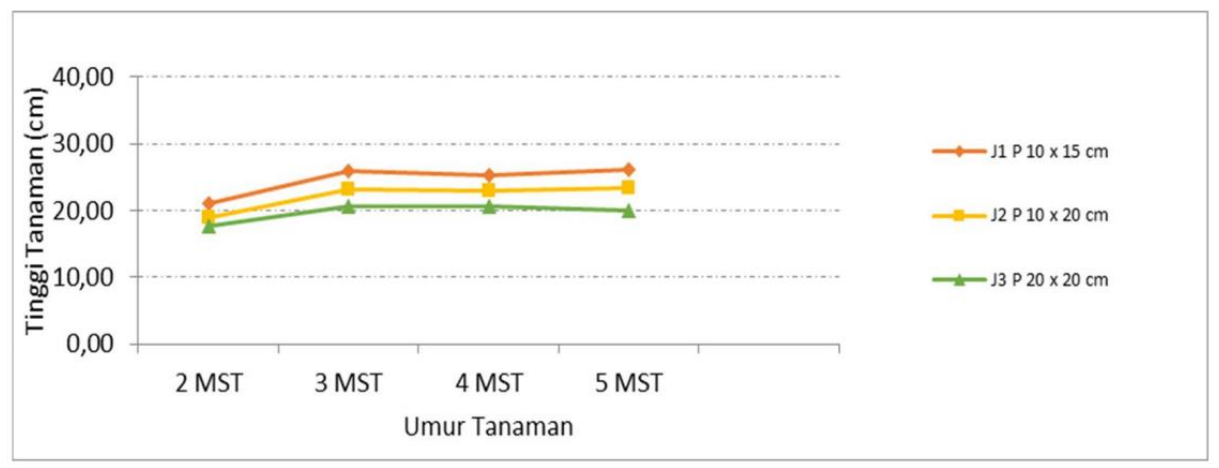

Gambar 1. Grafik laju pertumbuhan tinggi tanaman bawang merah dengan berbagai jarak tanam pada polatanam tanam tumpangsari pada umur 2-5 MST

Jarak tanam bawang merah memberikan pengaruh yang sama terhadap jumlah daun bawang merah. Kenyataan ini dimungkinkan oleh respon genetik yang sama terhadap kondisi lingkungan yang tercipta dari kepadatan yang berbeda, terutama unsur hara dan penyinaran yang masih terpenuhi untuk tanaman. Kenyataan ini dapat dilihat pada gambar di bawah ini. 


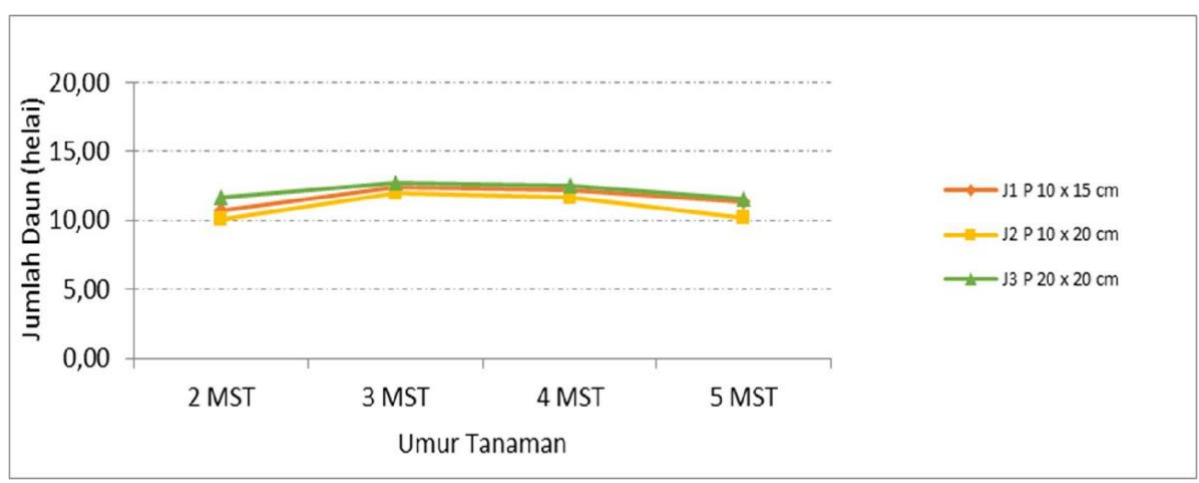

Gambar 2. Grafik laju pertumbuhan jumlah daun bawang merah dengan berbagai jarak tanam dengan sistem tanam tumpang sari pada umur 2-5 MST

\section{- Jumlah Umbi per rumpun, Bobot umbi per petak dan per hektar.}

Penggunaan beberapa jarak tanam bawang merah setelah dianalisis statistik memberikan pengaruh yang berbeda tidak nyata terhadap Jumlah umbi per rumpun, Bobot umbi per petak da per hektar (Tabel 2).

Tabel 2. Jumlah umbi per rumpun, Bobot Umbi per petak dan per hektar pada beberapa jarak tanam bawang merah dalam pola tanam tumpangsari dengan jagung.

\begin{tabular}{cccc}
\hline \multirow{2}{*}{ Jarak Tanam } & $\begin{array}{c}\text { Jumlah Umbi per } \\
\text { Rumpun (siung) }\end{array}$ & $\begin{array}{c}\text { Bobot Umbi per Petak } \\
(\mathrm{kg})\end{array}$ & $\begin{array}{c}\text { Bobot Umbi per Hektar } \\
\text { (ton) }\end{array}$ \\
\hline $20 \mathrm{~cm} \times 20 \mathrm{~cm}$ & 5,2 & 0,318 & 1,23 \\
$10 \mathrm{~cm} \times 20 \mathrm{~cm}$ & 5,0 & 0,178 & 0,78 \\
$10 \mathrm{~cm} \times 15 \mathrm{~cm}$ & 4,7 & 0,065 & 0,29 \\
\hline KK $(\%)$ & 12,59 & 6,14 & 13,25 \\
\hline
\end{tabular}

Angka-angka pada kolom yang sama berbeda tidak nyata menurut uji F taraf $5 \%$

Tidak berbeda nyatanya pengaruh penggunaan beberapa jarak tanam terhadap beberapa pengamatan di atas, disebabkan oleh kondisi lingkungan yang cukup lembab karena tingginya curah hujan pada saat penelitian berlangsung. Kelembababan yang cukup tinggi (86\%) menjelang panen mengakibatkan perkembangan umbi berkurang karena terserang hama dan penyakit. Gangguan ulat grayak (Spodoptera exigua) ) dan jamur fusarium (Fusarium oxysporum) mengakibatkan daun menjadi kuning dan layu yang selanjutnya menyebabkan terganggunya translokasi fotosintat ke umbi. Menurut Sumarni et al. (2012) daun yang menguning pada tanaman dapat menganggu proses fotosintesis, sehingga tanaman tidak mampu menghasilkan umbi yang sempurna akibat dari produksi fotosintat menurun.

\section{Pengamatan Tanaman Jagung}

\section{- Tinggi Tanaman dan Jumlah Daun}

Hasil analisis statistik pada data pengamatan tinggi tanaman dan jumlah daun jagungberbeda tidak nyata pada penggunaan beberapa jarak tanam bawang merah dalam tumpangsari dengan jagung (Tabel 3).

Tabel 3. Tinggi tanaman dan Jumlah Daun jagung pada beberapa jarak tanam bawang merah dalam polatanam tumpangsari umur 8 MST.

\begin{tabular}{lcc}
\hline Jarak Tanam Bawang Merah & Tinggi Tanaman $(\mathrm{cm})$ & Jumlah Daun (helai) \\
\hline $10 \mathrm{~cm} \times 15 \mathrm{~cm}$ & 146,1 & 10,67 \\
$10 \mathrm{~cm} \times 20 \mathrm{~cm}$ & 141,7 & 10,60 \\
$20 \mathrm{~cm} \times 20 \mathrm{~cm}$ & 134,2 & 9,73 \\
\hline KK $(\%)$ & 7,43 & 8,38 \\
\hline
\end{tabular}

Angka-angka pada kolom yang sama berbeda tidak nyata menurut uji $F$ taraf $5 \%$

Penggunaan beberapa jarak tanam bawang merah pada polatanam tumpangsari tidak memberikan pengaruh yang berbeda terhadap tinggi tanaman dan jumlah daun jagung. Tanaman jagung yang ditanam 2 minggu lebih awal dari tanaman bawang merah, mampu memanfaatkan faktor lingkungan secara optimal untuk pertumbuhannya. Tanaman akan tumbuh dan berkembang dengan optimal apabila cahaya, unsur hara dan air 
yang dibutuhkan tersedia dengan cukup. Tanaman jagung merupakan salah satu tanaman yang memiliki tingkat adaptasi yang baik terhadap kondisi cuaca dibandingkan bawang merah. Jagung merupakan tanaman yang tergolong C4 yaitu tanaman yang efisien dalam memanfaatkan cahaya, yang didukung juga dengan daun jagung yang memiliki tipe tegak sehingga lebih efisien dalam memanfaatkan energi matahari. Hasil penelitian Akil (2013) yang mendapatkan tinggi tanaman jagung yang ditanampada saat tingkat hujan yang tinggi lebih rendah dari pada jagung yang di tanam pada saat tingkat hujan yang tidak terlalu tinggi, hal tersebut karena tanaman tidak mendapatkan penyinaran matahari secara maksimal.

\section{- Diameter dan Panjang tongkol, Bobot tongkol per petak dan per hetar.}

Beberapa jarak tanam bawang merah yang digunakan memberikan pengaruh yang berbeda tidak nyata terhadap diameter dan panjang tongkol jagung dalam polatanam tumpangsari (Tabel 4).

Tabel 4 . Diameter dan panjang tongkol, serta bobot tongkol per petak dan per hektar tanaman jagung dalam beberapa jarak tanam bawang merah pada polatanam tumpang sari.

\begin{tabular}{ccccc}
\hline Jarak Tanam & $\begin{array}{c}\text { Diameter Tongkol } \\
\text { Bawang Merah }\end{array}$ & $\begin{array}{c}\text { Panjang Tongkol } \\
(\mathrm{cm})\end{array}$ & $\begin{array}{c}\text { Bobot Tongkol } \\
\text { Per petak }(\mathrm{kg})\end{array}$ & $\begin{array}{c}\text { Bobot Tongkol } \\
\text { Per Hektar (ton) }\end{array}$ \\
\hline $10 \mathrm{~cm} \times 15 \mathrm{~cm}$ & 4,61 & 18,65 & 2,75 & 12,21 \\
$10 \mathrm{~cm} \times 20 \mathrm{~cm}$ & 4,56 & 17,57 & 2,63 & 11,69 \\
$20 \mathrm{~cm} \times 20 \mathrm{~cm}$ & 4,58 & 18,10 & 3,12 & 13,85 \\
\hline KK $(\%)$ & 2,34 & 6,15 & 11,59 & 11,60 \\
\hline
\end{tabular}

Keterangan: Angka-angka pada kolom yang sama berbeda tidak nyata menurut uji $\mathrm{F}$ taraf.5\%,

Tidak berbeda nyatanya penggunaan beberapa jarak tanam bawang merah terhadap beberapa komponen hasil tanaman jagung disebabkan oleh karena pertumbuhan tanaman jagung yang lebih optimal sejak awal, sehingga keberadaan tanaman lain (bawang merah) tidak begitu mempengaruhi. Tipe pertumbuhan Jagung yang lebih tinggi mampu memanfaatkan cahaya secara optimal. Demikian juga tipe perakaran jagung yang lebih dalam dan banyak dibandingkan bawang merah, dapat menyerap hara dengan baik tanpa berkompetisi dengan bawang merah.

Wibowo (2008), menyatakan bahwa proses fotosintesis akan menentukan akumulasi fotosintat yang bermanfaat bagi pertumbuhan. Pertumbuhan tanaman sangat dipengaruhi oleh tinggi rendahnya fotosintat yang dihasilkan melalui proses fotosintesis. Selanjutnya Hawayanti ( 2015), mengemukakan bahwa hasil tanaman jagung sangat erat kaitannya dengan produksi asimilat pada masa partumbuhan tanaman dan translokasinya ke komponen hasil. Produksi biomasa tanaman mengakibatkan pertambahan berat dan ukuran dari bagian tanaman. Bobot kering total merupakan salah satu penimbunan dari hasil asimilasi bersih selama pertumbuhan, semakin meningkat bobot kering tanaman menunjukkan proses fotosintesis berjalan dengan baik. Meningkatnya bobot pipilan kering, bobot kering akar, batang dan daun menunjukkan translokasi fotosintat berjalan baik ke bagian tersebut.

\section{- Nisbah Keteraan Lahan (NKL)}

Berdasarkan hasil ananalisis statistik terhadap nisbah kesetaraan lahan (NKL) pada polatanam tumpangsari bawang merah dengan jagung, memberikan hasil yang berbeda tidak nyata (Tabel 5 ).

Tabel 5. Nisbah Kesetaraan Lahan pada Pola Tanam Tumpangsari Bawang Merah dengan Jagung

\begin{tabular}{lc}
\hline Jarak Tanam Bawang Merah & Nisbah kesetaraan lahan (NKL) \\
\hline $20 \mathrm{~cm} \times 20 \mathrm{~cm}$ & 1,04 \\
$10 \mathrm{~cm} \times 15 \mathrm{~cm}$ & 1,02 \\
$10 \mathrm{~cm} \times 20 \mathrm{~cm}$ & 0,97 \\
\hline
\end{tabular}

$\mathrm{KK}=12,96 \%$

Keterangan: Angka-angka.pada kolom yang sama tidak berbeda nyata menurut uji $\mathrm{F}$ taraf 5\%.

Berdasarkan tabel di atas, dapat dilihat bahwa nilai NKL tidak dipengaruhi oleh jarak tanam bawang merah dalam polatanam tumpangsari dengan jagung. Namun nilai NKL pada jarak tanam $20 \mathrm{~cm} \times 20 \mathrm{~cm}$ dan 10 $\mathrm{cm} \times 15 \mathrm{~cm}$ lebih dari satu yaitu 1,04 dan 1,02, maka dalam hal ini pemanfaatan lahan lebih efesien atau menguntungkan dibandingkan jika ditanam masing-masing secara monokultur. Sesuai dengan pernyataan Putra et al. (2017) sistem tanam tumpang sari lebih menguntungkan apabila memiliki nilai nisbah kesetaraan lahan lebih besar dari satu. Namun pada tumpang sari bawang merah dengan jagung yang dilakukan nilai nisbah kesetaraaan lahan yang lebih dari satu belum dapat meningkatkan nilai ekonomi dari monokultur bawang merah. Sejalan dengan penelitian Lorina et al. (2015) yang mengatakan bahwa sistem tumpang sari brokoli dan bawang 
prei belum dapat meningkatkan nilai ekonomi dari sistem monokultur brokoli meskipun memiliki NKL yang lebih dari satu.

Jarak tanam tidak mempengaruhi keefektifan lahan yang digunakan, dua jarak tanam memberikan hasil yang menguntungkan namun pada jarak tanam $10 \mathrm{~cm} \times 20 \mathrm{~cm}$ memberikan nisbah kesetaraan lahan yang tidak menguntungkan tetapi angkanya mendekati satu. Hasil tanaman bawang merah dan jagung tumpang sari berbeda nyata dengan sistem tanam monokultur berarti sistem tanam yang digunakan berpengaruh terhadap hasil tanaman bawang merah.

\section{DAFTAR PUSTAKA}

Akil, M. 2013. Kebutuhan hara N, P dan K Tanaman Jagung Hibrida pada Lahan Kering di Kabupaten Gowa. Seminar Nasional Serealia: 1-13.

Direktorat Jenderal Tanaman Pangan. 2019. Kementan Pastikan Produksi Jagung Nasional Surplus. Jakarta

Hawayanti, E., N. Gofar, dan M. U. Harun. 2015. Peningkatan Pertumbuhan dan Produksi Jagung Manis Melalui Penerapan Beberapa Jarak Tanam dan Pupuk Hayati di Lahan Lebak. Prosiding Seminar Nasional Lahan Suboptimal, Palembang: 8-9 Oktober 2015. 1-10.

Kementerian Pertanian. 2018. Outlook Jagung, Komoditas Pertanian ubsektor Tanaman Pangan. Pusat Data dan Sistem Informasi Pertanian. ISSN. 1907- 1507 Jakarta. 89 hal.

Kusmiadi, R., C. Ona, dan E. Saputra. 2015. Pengaruh Jarak Tanam dan Waktu Penyiangan terhadap Pertumbuhan dan Produksi Bawang Merah (Allium ascalonicum L.) pada Lahan Ultisol di Kabupaten Bangka. Enviagro, Jurnal Pertanian dan Lingkungan 8(2): 63-71.

Muhsanati. 2011. Pengembangan Bahan Ajar mata Kuliah Ekologi Tanah dan Tanaman. Teaching Grant Program Hibah Kompetensi Berbasis Institusi: 155-163.

Putra, J. P. H., K. P. Wicaksono, dan N. Herlina. 2017. Studi Sistem Tumpang sari Jagung (Zea Mays L.) dan Bawang Prei (Allium porrum L.) Pada Berbagai Jarak Tanam. Jurnal produksi Tanaman 5(5): 748-755.

Ratri, C. H., R. Soelistyono, dan N. Aini. 2015. Pengaruh Waktu Tanam Bawang Prei (Allium porum L.) pada Sistem Tumpang sari Terhadap Pertumbuhan Dan Hasil Tanaman Jagung Manis (Zea mays L.). Jurnal Produksi Tanaman 3(5): 406-412.

Sumarni, Rosliani. R, dan Suwandi. 2012. Optimasi Jarak Tanam dan Dosis Pupuk NPK untuk Produksi Bawang Merah dari Benih Umbi Mini di Dataran Tinggi. Jurnal Hortikultura 22(2): 148-155.

Wibowo, W. 2008. Kajian Tingkat Populasi dan Konsentrasi Pupuk daun terhadap pertumbuhan dan Hasil Beberapa Varietas Jagung Hibrida Zea mays L. Tesis. Universitas Sebelas Maret, Surakarta. 